This work is licensed under a Creative Commons Attribution 4.0 International License https://creativecommons.org/licenses/by/4.0/

\title{
LANGUAGE EDUCATION: PROBLEMS AND POSSIBLE SOLUTIONS
}

\author{
Grigory Kazakov \\ Moscow State Institute of International Relations (University) \\ 76, Prospekt Vernadskogo, Moscow, 119454, Russia
}

\begin{abstract}
Although knowledge of foreign languages is now becoming increasingly necessary, language education in most parts of the world (with few exceptions) seems to be rather inefficient. This paper attempts to define the most common problems of general language instruction and their possible solutions. In the first part, linguistic, psychological, methodological and external factors affecting the learning process are singled out. In the second part, it is discussed how these problems could be solved and some practical measures are proposed.
\end{abstract}

Keywords: language education, foreign languages, methodology, psychological factors, polyglottery, applied linguistics

For citation: Kazakov, G. (2021). Language Education: Problems and Possible Solutions. Linguistics \& Polyglot Studies, 7(4), pp. 18-23. https://doi.org/10.24833/2410-2423-2021-4-28-18-23

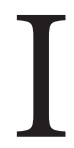

$\mathrm{n}$ many parts of the world, with the exception of several countries of Central and North Europe, general language education, unfortunately, so far seems to be rather inefficient despite the increasing demand for individuals who can be functional in multiple tongues in today's intense international communications. After studying a foreign language for years at school and university levels, people admit that they can barely have a basic conversation in it. Why does so much time of classes, paper of textbooks, teachers' work and public finance lead to such unsatisfactory results, and what can be done about it?

\section{Problems}

Gap between practical foreign language expertise and academic linguistics. In today's systems of education, the study of foreign languages and academic linguistics are regarded as separate (and sometimes even opposed) areas of knowledge and training. Many professional language users, interpreters and teachers often remain limited to their personal experience while practical command of foreign languages is not considered a requirement for linguistics and even language acquisition research in academia. It seems, however, that rapprochement between the language learners' and the academic communities would work for the common good and would facilitate overcoming the fragmentariness of knowledge in the study of language [17, p. 4-5], [12, p. 134-135], [1, p. 6-7]. 
Absence of instruction in the methodology of language learning. While higher education curricula for teachers of languages usually include a course in the methodology of language teaching, students are practically never instructed in the fundamental principles and applied techniques of language learning. It is, however, now generally admitted that accomplishments in the study of foreign languages depend more on one's educational self-management (self-motivation, self-discipline and use of individually geared learning methods and resources) than on external training [19, p. 3-4], [5, p. 72].

Lack of knowledge about the process and methods of language learning. It would probably not be too far from the truth to say that most individuals involved in language education do not have a scientifically grounded understanding of language learning as a psycholinguistic and biological process (largely due to the lack of relevant instruction mentioned above). Since the end of the 19th century, significant advances have been made in the methodology of language education. Besides the traditional method of grammar and translation, appeared such methods as the direct, the audio-lingual and the communicative ones, suggestopedia and others. Have been developed such instructional materials as Assimil self-teaching textbooks, Pimsleur and Michel Thomas listening courses, etc. One has to be familiar with them in order to choose the most convenient tool according to the needs of the learner. Meanwhile, many students and language teachers, unfortunately, do not even know these methods and materials, and the procedures and resources actually used in educational settings are often employed in an uncoordinated and inconsistent manner.

Negative experience. To a considerable degree, the difficulties of learning and using foreign languages at an adult age are often due to negative emotions associated with the study of languages in the past, especially in primary or secondary school. The problem could consist in the fact that one did not get on well with the teacher (there was no liking or mutual respect), that the student did not find (and the teacher did not help him find) an aspect of the language that would fascinate him (motivation was not aroused), or in the atmosphere of unfriendliness and fear in class.

Lack of confidence. Negative experience in the past naturally results in the lack of confidence. This problem consists in a low self-appraisal (which is a common psychological problem throughout the world), in the idea that one does not have "the ability to learn languages" (while all polyglots deny having a special ability), in the belief that a foreign language is something exceptionally difficult to learn (however, what can be difficult is not the language itself but the process and methods of learning it), and in the myth that only children can master languages successfully (while in fact age does impose limits for the natural and unconscious acquisition of the mother tongue, but not for subsequent foreign languages).

Limited ideas concerning what is possible. Many people have a short vision of what is possible in the field of languages. They find it barely achievable to speak a single foreign language fluently, and knowing several languages is considered something incredible. However, in reality polyglottery is possible and achievable. Simultaneous use of several languages in society is a natural state of affairs in many parts of the world. In the 21 st century, multilingualism is necessary and, thanks to modern technologies, affordable as never before.

Lack of concrete goals. Sometimes learners have vague ideas of what they want to achieve, such as "to increase language knowledge in general". In that case there will never be an end to this process and it will be difficult to estimate the effectiveness of the studies. It seems that it is better to have concrete practical objectives that could be regarded as tangible results of the classes, e.g. to read a book in the original, to understand a film without translation, or to explain oneself during a trip abroad, etc.

Confusing language, speech and the writing system. Usually a language as an object of study is perceived as one complex. However, Saussure's basic distinction between language as an abstract system of signs and speech as concrete uses of the language (in the form of spoken or written texts) seems important not only in linguistics theory but also in the field of educational practice. What should one learn and teach: language (i.e. rules of how the elements of language are functioning) or speech (i.e. common patterns of speaking)? What should be the proportion between these two components in classes and textbooks? These are the fundamental questions on which the structure of the educational process in relation to foreign languages will depend. Boris Belyaev suggests the following correlation: 10-20\% of language theory and $80-90 \%$ of speech practice $[4$, p. 149]. 
Another concept that must be distinguished is the writing system. Sometimes people who learn languages tend to perceive sounds and letters as the same, while a letter is only a possible conventional way of representing a particular sound. The script in general is a secondary system whose function is to reflect speech graphically. In terms of the learning process, the script can be more complicated than the language itself (as in Chinese and Japanese). In the latter case it may be reasonable to study the "substance" of the language and its writing system separately, as well as to use the phonetic transcription at the initial stages of study.

Confusing the stages of assimilation and practice. In general terms, learning a foreign language can be divided into two stages: "assimilation", the purpose of which is to internalize patterns of speech for basic communication (a good example of a textbook appropriate for this stage is Japanese for Beginners by Gakken), and "practice", when one learns more stylistically varied ways of expression [10, p. 105]. A common problem is that the activities and exercises appropriate for the stage of practice (when one basically expands his vocabulary) are introduced into that of assimilation (when one needs extensive and perhaps repetitive input of the most typical and frequent models of speech), or vice versa.

Insufficient input. There is a lot of evidence that a learner's proficiency in a foreign language is directly proportional to the amount of input (language material perceived through listening and reading) he has processed by his brain $[17$, p. 32], [9, p. 115], [13, p. 258-259]. To be internalized, this input has to be comprehensible (by means of transparent vocabulary, context or translation) and relevant to the needs and interests of the student. One of the most important reasons why the results of language education are so unsatisfactory in most parts of the world is that learners receive too little authentic foreign language input in classes and textbooks. For example, it has been calculated that during six years of studying English in junior high and high school, Japanese students only read some 40 thousand words in English [22, p. 17], while the latest findings show that to reach an intermediate functional level in a foreign language (B1-B2 in the European framework), one needs the input of about 1 million words [14]. That is to say, after six years of studies, Japanese children only receive $4 \%$ of the necessary input. This is because most of what they hear in class and read in their textbooks is not conversations and texts in English but explanations in their mother tongue.

Interrupted process of language learning. Typically, traditional language education is too extended in terms of time and poorly concentrated, while in order to speak a language confidently and fluently one has to study a little every day, especially at the initial stages. The command of a language is not a sum of memorized data, but rather a skill the development of which requires regular practice. It would be more productive to concentrate on learning a language on a daily basis for a limited time (a few months) than to extend this process for years studying only once or twice a week.

Concentration on memorizing isolated words. Sometimes students devote themselves to reading lists of foreign language words with translations in the hope of retaining them in memory (for example, this is often the case in Japan). This may even be a task from the teacher or an expectation on the part of examiners. However, the fact is that we do not speak with isolated words but with larger blocks (phrases). If one wants to learn something by heart, it would be more practical to memorize phrases or entire texts because this will not only enable one to use them in speech in their fixed form but will also show the natural way to combine language elements in a sentence.

Focusing on tests instead of general foreign language capacity. This is also a typical problem in East Asia. Many students do not aspire to improve their ability to understand and use, say, English in real life but only train themselves in taking standard written exams (such as TOEIC or TOEFL), whose scores are a formal criterion when applying for a university program or a job. However, one cannot learn the language from a collection of tests because the objective of the exam is usually not to teach something but to measure the knowledge of the language one already has.

Defects of formal education. These consist in such external factors (not directly related to the improvement of language learning methodology) as the need to maintain discipline in the classroom (particularly in secondary school), the schedule of classes and the textbooks imposed from above, the teacher's personal qualities (competence, manner of communication, physical and emotional state, enthusiasm and workload), etc. Besides, the existent system of academic qualifications seems to have little relevance to evaluating teaching capacities. Since language is a skill (like music or sport), having a PhD 
in linguistics does not necessarily make one a better foreign language teacher. While academic degrees do qualify one for research and for lectureship in theoretical subjects, professionalism in giving practical classes of language could, perhaps, be better demonstrated by language examination certificates, experience in translation and publication of textbooks. In this light, one can envision, in addition to the system of research degrees, the development of a parallel system of didactic qualifications.

\section{Possible solutions}

Polyglottery. Studying and modelling the phenomenon of polyglottery (consciously attained individual multilingualism) in wide educational practice is a highly promising source of new ideas and inspiration for the improvement of language training. If athletes try to follow the example of Olympic champions, and musicians, that of virtuosi, it seems quite logical that learning from the experience of polyglots, successful language learners par excellence, should be insightful and instructive too. To date, there is a whole corpus of published polyglots' memoirs, such as How I Learn Languages by Kato Lomb [18], The Art and Science of Learning Languages by Erik Gunnemark \& Amorey Gethin [7], Kak Stat' Poliglotom by Dmitry Spivak [23], How to Learn Any Language by Barry Farber [6], The Linguist: a Personal Guide to Language Learning by Steve Kaufmann [9], Speak Like a Native by Michael Janich [8], Bystroe Izuchenie Inostrannogo Iazyka ot Angliiskogo do Iaponskogo by Timur Baytukalov [3], How to Speak Any Language Fluently by Alex Rawlings [21], and others. The research literature on polyglottery developed in recent years consists of Kak Naiti Svoy Put' k Inostrannym Iazykam [19] \& Govorim, Chitaem, Pishem [20] by Dina Nikulicheva, Babel No More: the Search for the World's Most Extraordinary Language Learners by Michael Erard [5], proceedings of four conferences (including the present volume), a series of publications by Dina Nikulicheva and Grigory Kazakov in the Journal of Psycholinguistics, and separate articles by Erik Gunnemark, Stephen Krashen, Timothy Keeley, Martin Bragalone, Alexander Arguelles, Kenneth Hyltenstam, Olessia Jouravlev, Noprival Noprival, and others (for a review see [15]).

Introducing methodology of language learning into curricula. This could be organized as a special course for language teachers and applied linguists as part of their higher education or in professional development seminars. An experimental course of this kind was offered at the Faculty of Foreign Languages and Area Studies, Moscow State University, in 2012 [11]. Relevant topics can also be added to courses on language teaching that already exist in university curricula. For the broader audience of other language students, fundamentals of the learning methodology could be presented in introductory sections of foreign language classes. This outline should probably contain a discussion of the nature and principles of the language acquisition process as well as recommendations concerning efficient learning materials and techniques (for an example by reference to English see [10]). Such instruction should always include psychological encouragement of students for subsequent language study (a set of mental exercises to this end is developed in the books by Dina Nikulicheva) [19], [20].

Wider use of video and audio materials. It seems true that currently in language teaching there is too much concentration on printed text, and listening and video materials are used insufficiently, while modern technologies allow it. This is unfortunate because such resources provide exposure to authentic language in the form which is closest to its actual use and also because learners enjoy them. It seems probable that if school students simply watched interesting films in foreign languages with subtitles during classes, they would learn much more (in terms of understanding and speaking the language) than from reading traditional textbooks, and, besides, they would be more motivated to participate in the classes. For example, many Swedes, regardless of their age and profession, speak English (and sometimes other European languages) quite fluently. As they say, the main reason for this is that in Sweden foreign films are not dubbed and are always shown in the original language with subtitles.

Timur Baytukalov argues that in the hierarchy of learning materials, video has the supreme rank, audio recordings have the intermediate one and printed text occupies the lowest position. This is because in the case of a written text, the student has to "invent" how the phrases he reads are pronounced and used in a real conversation, while video contains the widest possible informative context (sound, facial ex- 
pression, gestures, setting, etc.), thanks to which one can understand and assimilate more [3, p. 28, 109]. This does not mean that one has to dispense with printed books; it only means that it is not practical to limit oneself to them and that it is better to use everything together. Baytukalov proposes the following succession in the process of learning a language: first work with a listening course to the point when you can transcribe phonetically the foreign phrases you hear without difficulty; then devote yourself to video courses; and finally continue the study watching original films with subtitles. The author writes that, in his opinion, for foreign language teachers, "creating double subtitles and glossaries for the available video and audio material, as well as creating new video courses... should be their main activity (apart from teaching the foreign language itself in classes)" [3, p. 154].

Extensive reading. Reading is, arguably, the main source of input for full-scale language acquisition in the case of developed literary languages since only reading can provide a sufficient diversity of authentic texts and vocabulary on a wide variety of topics. Intensive reading implies a conscious focus on the grammatical form of a separate text and analysis of individual words in it, while extensive reading aims at understanding the general content of large amounts of writing and at guessing the meaning of unknown lexical units from context [2, p. 82, 353]. If the purpose of learning a language is its practical use for communication and for access to information from foreign sources, the available data on the process of language acquisition seems to favour the extensive approach [17, p. 73]. If one is not yet fluent enough to read authentic literature, parallel (bilingual) texts and graded readers can be used as intermediary steps. For a beginning learner of a new language, it will thus be reasonable to start with bilingual editions, then move to adapted literature and finally enjoy the originals [16, p. 12483].

Studying subjects of interest through the target language. Language is not an aim in itself but an instrument of communication and cognition and is acquired best when used this way. Engaging in activities where the target language is not the purpose but a medium of obtaining information related to one's personal interests (art, science, technology, business, international affairs, travelling, sport, hobbies, etc.) can be highly motivating, rewarding and productive. This can include reading professional literature, watching specialized talks, taking classes on different subjects offered in the target language, etc. Focusing on the content from these sources (provided it is comprehensible) rather than on the verbal structure will be a sign that language acquisition is underway $[17$, p. 66].

\section{Conclusion}

The problems discussed above can be classified into the following types: linguistic (insufficient input); psychological (negative experience, the lack of confidence, limited ideas concerning what is possible, the lack of concrete goals); methodological (the absence of specific instruction, the lack of relevant knowledge, confusing language, speech and writing as well as the stages of assimilation and practice, interruptions in the study process, concentration on memorizing isolated words, an excessive focus on tests); and extralinguistic or external ones (the gap between language learning and linguistics, defects of formal education).

Linguistic problems are related to the very nature of language acquisition. Psychological difficulties characterize the emotional and volitional state of the learner. Methodological deficiencies are connected with the structure and priorities of the learning process. Extralinguistic factors proceed from the broader environment where the study process takes place. While all of them play a role in preventing the achievement of better results, there is evidence that both research literature and learners themselves emphasize psychological problems as the primary obstacles to successful language acquisition [24, p. 48]. These, therefore, need to be dealt with in the first place.

To conclude, it can be said that today's language education in general is not very effective (in the sense that much time, money and effort is wasted without achieving satisfactory results) and some changes are necessary. However, although there are many problems, there are also ideas and means to solve them. In general, it seems that educational systems have to move from the language teaching paradigm to that of language learning, where the teacher's role will be to motivate and consult students in their self-studies. The improvement process should probably take place both in the form of rationalizing formal training 
programs on the basis of data and achievements of language acquisition methodology, and in terms of developing informal and independent public initiatives that foster interest in languages, exchange of ideas and experiences, and mutual support among learners.

(C) G. Kazakov, 2021

\section{References}

1. Arguelles, A. The price of polyglottery: the case for establishing a Polyglot Institute. International Conference on Multilingual Proficiency: Language, Polyglossia and Polyglottery (W. Finke \& L. Ashley eds.). New York: The American Society of Geolinguistics, 2016. P. 1-14.

2. Azimov, E. \& Shchukin, A. Novy Slovar' Metodicheskikh Terminov i Poniatiy (Teoriia i Praktika Obucheniia Iazykam) [New Dictionary of Methodological Terms and Concepts: Theory and Practice of Language Teaching]. Moscow: IKAR Press, 2009. 448 p.

3. Baytukalov, T. Bystroe Izuchenie Inostrannogo Iazyka ot Angliiskogo do Iaponskogo [Learning a Foreign Language Fast from English to Japanese]. Moscow: Ripol Classic, 2008. 160 p.

4. Belyaev, B. Novoe v psikhologii obucheniia inostrannym iazykam [New trends in psychology of foreign language learning]. Psikhologicheskie i Psikholingvisticheskie Problemy Vladeniia i Ovladeniia Iazykom [Psychological and Psycholinguistics Problems of Language Use and Language Learning] (A. Leontiev \& T. Ryabova eds.). Moscow University Press, 1969. P. 143-155.

5. Erard, M. Babel No More: the Search for the World's Most Extraordinary Language Learners. New York: Free Press, 2012.306 p.

6. Farber, B. How to Learn Any Language. New York: MJF Books, 1991. 172 p.

7. Gethin, A. \& Gunnemark, E. The Art and Science of Learning Languages. Oxford: Intellect, 1997. 352 p.

8. Janich, M. Speak Like a Native: Professional Secrets for Mastering Foreign Languages. Boulder: Paladin Press, 2004.122 p.

9. Kaufmann, S. The Linguist: a Personal Guide to Language Learning. The Linguist Institute, 2003. 146 p.

10. Kazakov, G. Some ideas on how to improve one's English. Studies in Foreign Languages (Daito Bunka University, Tokyo), 2015, 16. P. 103-108.

11. Kazakov, G. A university course in methods of accelerated language learning: ideas and experience. Multilingual Perspectives in Geolinguistics (W. Finke \& H. Kitabayashi eds. in chief). Raleigh: Lulu Press, 2015. P. 144-152.

12. Kazakov, G. Polyglottery as a science. International Conference on Multilingual Proficiency: Language, Polyglossia and Polyglottery (W. Finke \& L. Ashley eds.). New York: The American Society of Geolinguistics, 2016. P. 133-137.

13. Kazakov, G. Syezd poliglotov v Bratislave: Polyglot Gathering 2017 [Polyglot Gathering 2017 in Bratislava]. Journal of Psycholinguistics, 2017, 3 (33). P. 258-260.

14. Kazakov, G. How much input do we need to learn a language? New Perspectives in Psycholinguistic Research: Language, Culture, Technologies. Online 12th ISAPL International Congress. June 3-5, 2021. Book of Abstracts (L. Scliar-Cabral et al. eds.). ISAPL, 2021. P. 183-184.

15. Kazakov, G. Research on polyglottery: sources of data. EDULEARN21 Proceedings. 2021. P. 8290-8296. DOI: 10.21125/edulearn.2021.1670.

16. Kazakov, G. Parallel translation as a language learning instrument. EDULEARN21 Proceedings. 2021. P. 12478-12484. DOI: 10.21125/edulearn.2021.2644.

17. Krashen, S. Principles and Practice in Second Language Acquisition. Phoenix ELT, 1995. 202 p.

18. Lomb, K. Polyglot: How I Learn Languages. Berkeley-Kioto: TESL-EJ, 2008. 215 p.

19. Nikulicheva, D. Kak Naiti Svoy Put'k Inostrannym Iazykam: Lingvisticheskie i Psikhologicheskie Strategii Poliglotov [How to Find Your Way to Foreign Languages: Polyglots' Linguistic and Psychological Strategies]. Moscow: Flinta-Nauka, 2009. 304 p.

20. Nikulicheva, D. Govorim, Chitaem, Pishem: Lingvisticheskie i Psikhologicheskie Strategii Poliglotov [Speaking, Reading, Writing: Polyglots' Linguistic and Psychological Strategies]. Moscow: Flinta-Nauka, 2013. 288 p.

21. Rawlings, A. How to Speak Any Language Fluently. London: Little, Brown Book Group, 2017. 224 p.

22. Seikei Freshers' English Extensive Reading Teacher's Manual. $3^{\text {rd }}$ ed. Tokyo: Seikei Institute for International Studies (Seikei University), 2015. 18 p.

23. Spivak, D. Kak Stat' Poliglotom [How to Become a Polyglot]. Leningrad: Lenizdat, 1989. 144 p.

24. Zudilin, M. Trudnosti pri Osvoenii Inostrannogo Iazyka dlia Tseley Mezhkul'turnogo Obshcheniia i Podkhody k ikh Preodoleniiu [The Difficulties in Second Language Acquisition for Cross-cultural Communication and Approaches to Overcoming Them]. Moscow University for the Humanities, 2017. 59 p.

\section{About the author:}

Grigory Kazakov, PhD, is Senior Lecturer at the Department of English No.3, Moscow State Institute of International Relations (MGIMO). Research interests: language education, polyglottery, psycholinguistics, language and religion, translation of sacred texts, Scouting pedagogy.

E-mail: g.kazakov@my.mgimo.ru 